\title{
Using large benthic macrofauna to refine and improve ecological indicators of bottom trawling disturbance
}

McLaverty, Ciaran; Eigaard, Ole Ritzau; Gislason, Henrik; Bastardie, Francois; Brooks, Mollie Elizabeth; Jonsson, Patrik; Lehmann, Andreas; Dinesen, Grete E.

Published in:

Ecological Indicators

Link to article, DOI:

10.1016/j.ecolind.2019.105811

Publication date:

2020

Document Version

Peer reviewed version

Link back to DTU Orbit

Citation (APA):

McLaverty, C., Eigaard, O. R., Gislason, H., Bastardie, F., Brooks, M. E., Jonsson, P., Lehmann, A., \& Dinesen, G. E. (2020). Using large benthic macrofauna to refine and improve ecological indicators of bottom trawling disturbance. Ecological Indicators, 110, [105811]. https://doi.org/10.1016/j.ecolind.2019.105811

\section{General rights}

Copyright and moral rights for the publications made accessible in the public portal are retained by the authors and/or other copyright owners and it is a condition of accessing publications that users recognise and abide by the legal requirements associated with these rights.

- Users may download and print one copy of any publication from the public portal for the purpose of private study or research.

- You may not further distribute the material or use it for any profit-making activity or commercial gain

- You may freely distribute the URL identifying the publication in the public portal 


\section{Using large benthic macrofauna to refine and improve ecological indicators of bottom trawling disturbance}

Ciarán McLaverty ${ }^{1,}$, , Ole R. Eigaard ${ }^{1}$, Henrik Gislason ${ }^{1}$, Francois Bastardie ${ }^{1}$, Mollie E. Brooks ${ }^{1}$, Patrik Jonsson ${ }^{2}$, Andreas Lehmann ${ }^{3}$, Grete E. Dinesen ${ }^{1}$

${ }^{1}$ DTU Aqua, National Institute of Aquatic Resources, Denmark

${ }^{2}$ Department of Aquatic Resources, Institute of Marine Research, Swedish University of Agricultural Sciences, 45330 Lysekil, Sweden

${ }^{3}$ GEOMAR Helmholtz Centre for Ocean Research, Düsternbrooker Weg 20, 24105 Kiel, Germany

*Corresponding author: cimc@aqua.dtu.dk. Technical University of Denmark, National Institute of Aquatic Resources, Kemitorvet, Building 201, Room 049, 2800 Kgs. Lyngby, Denmark.

\section{Keywords}

Keywords: benthic community; benthic indicators; ecosystem-based approach; fisheries management; functional traits; seafloor disturbance; trawling impacts.

\section{Abstract}

Bottom trawling alters the abundance, diversity, size-composition, and function of benthic communities. However, the ability to detect these impacts over large spatial scales can be obscured by various complicating factors, such as community adaptation to disturbance and co-varying environmental conditions. An ecosystem-based approach to fisheries management therefore requires ecological indicators which can 'disentangle' trawling effects from other natural and human drivers, and respond effectively to shifts in ecological quality. We collected benthic macrofaunal samples at 21 sites across a Norway lobster Nephrops norvegicus fishing ground in the Kattegat, and separated the benthic community into small $(1-4 \mathrm{~mm})$ and large $(>4 \mathrm{~mm})$ size fractions. Four taxonomic indicators (total density, species density, Shannon diversity, and biomass) and four functional indicators (functional diversity, functional richness, functional evenness, and functional dispersion) were calculated based on each size fraction, and the two fractions combined (pooled community). Here, we compare the ability of these indicators to detect trawling impacts across size categories. We show that indicators derived from large macrofauna were highly effective in this regard, and were less influenced by other environmental drivers, such as depth, sediment grain size, bottom current velocity, salinity, and temperature. This suggests that the taxonomic and functional characteristics of benthic communities display a size-dependent sensitivity to trawling disturbance, and therefore community metrics based on large benthic macrofauna may provide useful indicators. By contrast, indicators derived from the small fraction performed poorly, and those based on the pooled community demonstrated a varied ability to detect trawling. Small macrofauna are typically characterised by high density, diversity, and population growth rates, and their relative resilience to trawling may mask the response of the more sensitive 
macrofauna. This highlights an underlying issue with calculating indicators based on the whole benthic community. The approach outline here is easily applied, improves indicator performance, and has the potential to reduce laboratory workloads due to the fewer taxa and individuals required for analyses. 


\section{Introduction}

In recent years, the mapping and quantification of commercial trawling effort has greatly improved. This has come about due to the increased availability of spatially resolved information on fishing vessel activities, and the development of open source methods to estimate fishing effort (Bastardie et al., 2010; Hintzen et al., 2012). As a result, there is an improved understanding of the distribution of commercial trawling effort (Amoroso et al., 2018; Eigaard et al., 2017; Puig et al., 2012), and how gradients of trawling intensity alter the structure and ecological functioning of benthic macrofaunal communities (Bolam et al., 2017; Hiddink et al., 2017; Hinz et al., 2009; Tillin et al., 2006). Growing societal concern regarding fisheries effects has prompted the adoption of an 'Ecosystem Approach to Fisheries Management' (EAFM) (FAO, 2003) in the European Union. This has seen increased scientific interest and resources dedicated to the monitoring and assessment of 'Sea-floor Integrity' (Anon., 2010) and 'Good Environmental Status' of seafloor ecosystems, under the European Union Marine Strategy Framework Directive (MSFD) (Anon., 2008). By definition, an EAFM requires assessments of human impacts at the level of species, communities, and ecosystems to guide management advice. Ecological indicators are often a favoured instrument in this regard as they are easily calculated, monitored, and interpreted. However, in order to be effective, indicators should be sensitive to changes in ecological state, capture and convey information on the ecosystem, and not be overly affected by short-term variation or auxiliary drivers. Measuring all aspects of ecosystem state is neither practical nor possible, and well-designed indicators of bottom trawling impacts are therefore required to support management (Rice et al., 2012; Van Hoey et al., 2010).

As knowledge of the benthic effects of trawling has advanced, various co-varying and interacting factors have also been revealed. These can include the sensitivity of specific seabed habitats (Kaiser et al., 2006), the impact of different gear types (Eigaard et al., 2016; Hiddink et al., 2017), the magnitude of background human and natural disturbance (Diesing et al., 2013; Van Denderen et al., 2015), and gradual adaptations of macrofaunal communities to disturbance (Kaiser et al., 2000; Reiss et al., 2009). Alone, or in combination, such factors can obscure the measurable effects of trawling in benthic communities, and may explain why indicators sometimes display varied performance (Atkinson et al., 2011; Kaiser et al., 1998; Mangano et al., 2014). On the other hand, experimental and model based studies have revealed that large macrofauna are disproportionately sensitive to chronic trawling disturbance (Duplisea et al., 2002; Jennings et al., 2001; McConnaughey et al., 2005; Queirós et al., 2006). This vulnerability is linked to a relationship between body size and several key life history traits (Begon et al., 2006), whereby larger macrofauna tend to grow and reach maturity at a slower rate, have comparatively lower mortality and population growth rates, and are therefore more vulnerable to trawling induced mortality. Although small benthic fauna are also vulnerable trawling 
disturbance (Hinz et al., 2008), they often display relatively high growth and turnover rates, resulting in shorter recovery times.

While body size and sensitivity may vary across taxa, sensitivity may also change within the lifespan of an individual. During development from offspring to adult, sensitivity to physical disturbance can vary across size classes, trophic levels, and functional roles (Brose et al., 2016). For this reason, indicators based on e.g. the fraction of individuals above a certain minimum body size have been suggested and applied to monitor fish communities (Greenstreet et al., 2011; Shin et al., 2005), yet no such size-based indicators exist for benthic macrofauna. Recent studies by Hiddink et al., (2018) and Rijnsdorp et al., (2018) have shown that the relative abundances of long-lived macrofauna can indicate the sensitivity of benthic communities to trawling. This approach combines information on age composition of the community with fishing pressure data, and allows for the assessment of risks and impacts of trawling to taxa with defined longevity or recovery times (Hiddink et al., 2018). While this approach has shown to be effective, the longevity of macrofauna can be difficult to measure, may be be uncertain, and may be lacking for many species in less studied areas. It would therefore be advantageous if macrofaunal indicators of trawling impacts could be devised based on the size composition of the benthic organisms. Such indicators could be easily and accurately quantified, would not require knowledge of life history traits, would have the potential to be applied across habitat type and geographic region, and could potentially reduce sample processing times.

The main objective of this study is to explore if the performance of several taxonomic and functional indicators of trawling disturbance would improve if they were based on large macrofauna, rather than the whole community. To test this, data were collected in a fishing ground with a long history of bottom trawling. Sampling sites were selected to represent a wide spatial gradient of trawling intensity, ranging from zero (determined by long-standing closed areas) to regionally high trawling intensities. During sampling, sieves were used to separate the benthic community into two size fractions. Eight macrofaunal indicators were then calculated within each size fraction (small and large), as well as the fractions combined (pooled community). We investigate and compare the ability of these indicators to detect bottom trawling impacts across size categories using generalised linear mixed models (GLMMs). 


\section{Materials and Methods}

\subsection{Study area}

The Kattegat is a shallow transitional sea separating the marine North Sea and the brackish Baltic Sea (Figure 1). Its seabed is composed of sandy sediments in the west, and of mud and mixed sediments in the north, east, and deeper areas (Figure 1b). Physical conditions on the seabed are characterised by gradients in salinity, temperature, current velocity, and by a two-layer stratified flow pattern. An inflow of saline water from the North Sea occurs in the deeper areas, which is offset by an outflow of brackish water from the Baltic Sea at the surface. The two water masses are separated by a pycnocline which sits between $15 \mathrm{~m}$ (westwards) and 25m (eastwards) (Al-Hamdani et al., 2007). Commercial fishing for cod Gadus morhua (Linnaeus, 1758) and plaice Pleuronectes platessa (Linnaeus, 1758) has taken place in the Kattegat for over 100 years (Petersen, 1918). In recent years, high fishing effort has led to significant declines in the cod population and associated quota (Svedäng and Bardon, 2003; ICES, 2018). Conversely, there has been a considerable rise in landings of Norway lobster Nephrops norvegicus (Linnaeus, 1758). Although this may occur as a result of population increase (ICES, 2018b), or community shifts associated with reduced predation pressure (Howarth et al., 2014), time series data of commercial CPUE (catch per unit effort) suggest that increased fishing effort is the likely explanation (Eggert and Ulmestrand, 1999). Nephrops, now the primary target species in the Kattegat, is caught almost exclusively by Danish and Swedish vessels using demersal otter trawls (Hornborg et al., 2017). As Nephrops reside in shallow burrows, the fishery is characterised by relatively low catchability and high trawling intensity. As a result, the Kattegat is an area of relatively high trawling intensity at European (Eigaard et al., 2017) and global scale (Amoroso et al., 2018). Based on trawling effort in 2017, we estimate that $\sim 53 \%$ of all sublittoral mud habitat in the Kattegat (A5.3 - EUNIS level 3) (Figure 1b) was impacted by mobile bottom-contacting fishing gear. 
Figure 1: Map of sampling sites in respect to (a) trawling effort and (b) EUNIS Level 3 habitat types. Trawling intensity is described as the swept Area Ratio (SAR), and represents the cumulative trawling effort over 3 years (September 2013 to September 2016) for all Danish and Swedish vessels $>12 \mathrm{~m}$, using bottom contacting gears.
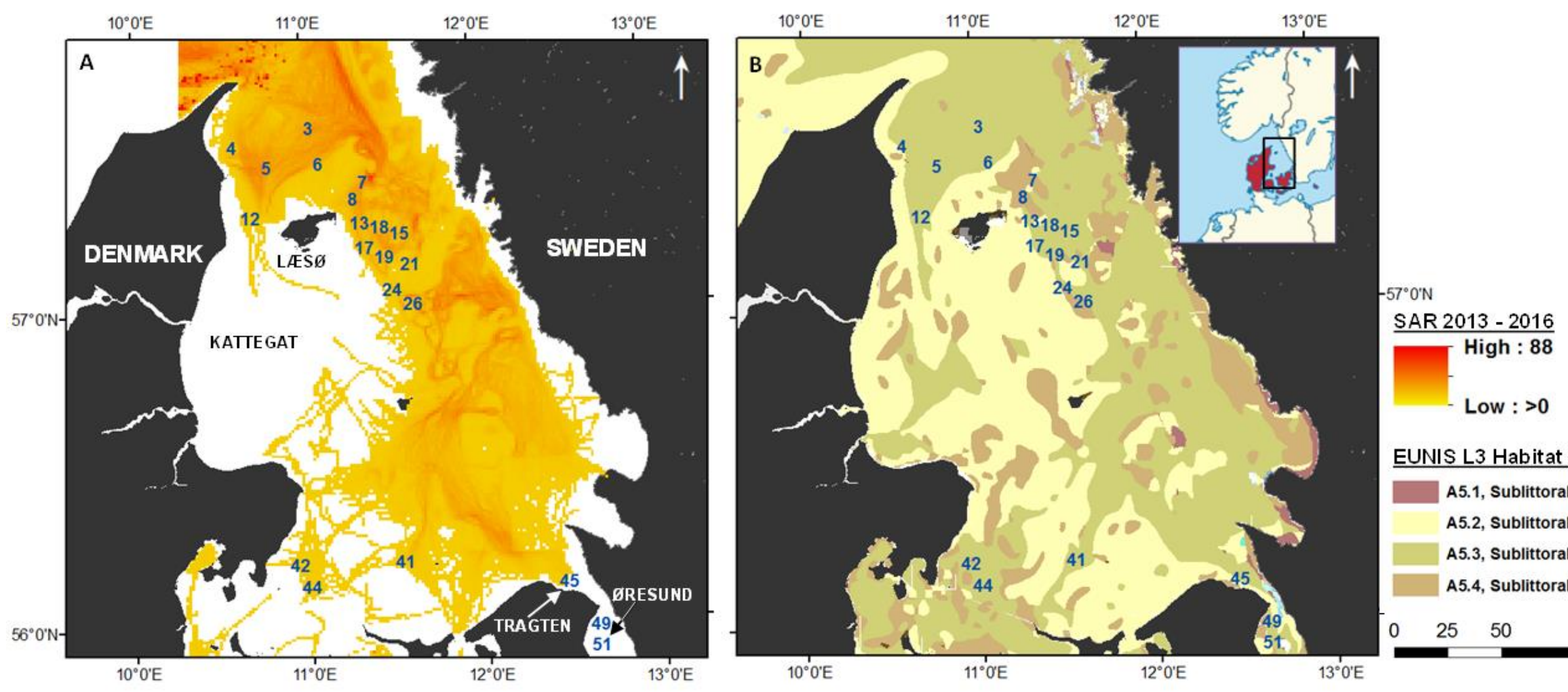

\section{EUNIS L3 Habitat type}

A5.1, Sublittoral coarse sediment A5.2, Sublittoral sand A5.3, Sublittoral mud

A5.4, Sublittoral mixed sediments $25 \quad 50$ 100 Kilometers 


\subsection{Sampling design}

Sampling sites were selected within areas characterised by the sediment type and depth suitable for Nephrops. The locations of sites were restricted to Danish waters and were chosen based on, i) a minimum depth of $15 \mathrm{~m}$, ii) mud (EUNIS A5.3) and mixed sand/mud (EUNIS A5.4) habitat (Figure 1b), iii) within a gradient of trawling intensity between 2013 -2016 (see section 2.7 - Estimating trawling pressure) (Figure 1a). Furthermore, some sites were determined by side scan sonar and consultation with local fishermen. As depth has been shown to be a potentially confounding factor in similar studies (Pommer et al., 2016), we selected areas of high and low trawling intensity in both shallow and deeper areas. The sampling design also included three sites located in areas subject to long-standing trawling closures; two in the Øresund, and the a third in nearshore areas of the 'Tragten' (Figure 1a). These areas have been subject to a trawl ban since 1932 under a Danish-Swedish Royal Convention (Ministry of Foreign Affairs of Denmark, 1933a; 1933b, 2009). Comparability of abiotic habitat characteristics were verified post-sampling by means of statistical analysis (detailed in the section 2.8 Environmental drivers).

\subsection{Data collection and sample processing}

Macrofauna communities were sampled at 21 sites (Figure 1) between 22 September and 6 October 2016. Five sediment samples were taken at each site using a $0.1 \mathrm{~m}^{2}$ Van-Veen grab. Four samples were processed for faunal analysis, and a fifth was sub-sampled for particle size analysis (PSA) and organic content. The faunal samples were sieved consecutively over $4 \mathrm{~mm}$ and $1 \mathrm{~mm}$ mesh sizes to separate the community into two size fractions. A $1 \mathrm{~mm}$ mesh size is widely used as benthic macrofauna are generally defined as metazoans retained by a $1 \mathrm{~mm}$ sieve, and a $4 \mathrm{mmthreshold} \mathrm{is} \mathrm{used} \mathrm{to} \mathrm{distinguish} \mathrm{larger} \mathrm{macrofauna} \mathrm{(also} \mathrm{known} \mathrm{as}$ megafauna). The sieved samples were then fixed in $4 \%$ borax-buffered formaldehyde in ambient seawater. In the laboratory, all animal material were identified to the lowest taxonomic level possible, and biomass estimates per species were determined as ash-free dry weight. All tubicolous polychaetes were removed from their tubes prior to weighing. Taxa were validated and standardised in accordance with World Register of Marine Species (WoRMS Editorial Board, 2018). The size-separation the community provided three datasets carried forward for analysis; the $1-4 \mathrm{~mm}$ (small) fraction, the $\geq 4 \mathrm{~mm}$ (large) fraction, and the two fractions combined (pooled community). Samples acquired for PSA and LOI\% were first frozen on board at $18^{\circ} \mathrm{C}$. PSA was undertaken via mass loss following wet sieving (Danish Standard (DS) 405.9), and resulted in the estimation of mud\% $(<63 \mu \mathrm{m})$, sand\% $(0.063-2 \mathrm{~mm})$, and gravel\% $(\geq 2 \mathrm{~mm})$. Organic content was estimated via loss-on-ignition (LOI\%), and calculated by mass loss of $4 \mathrm{mg}$ of homogenised sediment placed in a muffle furnace at $560^{\circ} \mathrm{C}$ for 4 hours, or until a constant weight was achieved (DS 204). 


\subsection{Biological trait classification}

An overview of the biological traits and associated categories (modalities) used to describe the functional characterises of the community is presented in Table 1. Some 10 traits and 48 descriptive modalities were developed by Bolam et al.(2017), based on their potential sensitivity to trawling. As marine taxa often exhibit more than one modality within a trait (e.g. multiple feeding modes), we followed a 'fuzzy coding' approach (Chevene et al., 1994). If a species exhibited full affinity to a single modality with in a trait (e.g. age), a score of 3 was assigned. Where species exhibited more than one modality, they were assigned a score relative to its importance (e.g. a predator which occasionally scavenges was coded as Predator $=2$, Scavenger $=1$ ). After coding, the scores for each modality were standardised to 1 within each trait type. The coded trait scores (taxa-by-trait matrix) were then combined with abundance data (abundance-by-site), to generate a trait-bysite matrix.

Table 1: Biological traits and associated modalities used in the study

\begin{tabular}{|l|l|}
\hline Trait & Modalities \\
\hline Size range & $<10 \mathrm{~mm}|11-20 \mathrm{~mm}| 21-100 \mathrm{~mm}|101-200 \mathrm{~mm}| 201-500 \mathrm{~mm} \mathrm{|}>500 \mathrm{~mm}$ \\
\hline Longevity & $<1$ year | 1-<3 years | 3-10 years | >10 years \\
\hline Larval development & Planktotrophic | Lecithotrophic | Direct \\
\hline Morphology & $\begin{array}{l}\text { Soft | Crustose | Cushion | Stalked | Tunic | Exoskeleton (chitin/calcium } \\
\text { carbonate) }\end{array}$ \\
\hline Egg development & $\begin{array}{l}\text { Asexual/Budding | Sexual: shed eggs pelagic | Sexual: shed eggs benthic | Sexual: } \\
\text { brood eggs }\end{array}$ \\
\hline Living habit & $\begin{array}{l}\text { Tube-dwelling | Burrow-dwelling | Free-living | Crevice/hole/under stone | } \\
\text { Attached to substratum | Epi/endozoic/phytic }\end{array}$ \\
\hline Sediment position & Surface | Infauna: 0-5cm | Infauna: 6-10cm | Infauna: >10cm \\
\hline Feeding mode & $\begin{array}{l}\text { Suspension | Scavenger/Opportunist | Surface Deposit | Subsurface deposit | } \\
\text { Predator | Parasite }\end{array}$ \\
\hline Mobility & mob Sessile | Burrower | Swim | Crawl/creep/climb \\
\hline Bioturbators & $\begin{array}{l}\text { Diffusive mixing | Surface deposition | Downwards conveyer | Upward Conveyor } \\
\text { | None }\end{array}$ \\
\hline
\end{tabular}

\subsection{Ecological indicators}

Ecological indicators were based on the benthic macrofauna, and chosen to reflect the ecological, taxonomic, and functional characteristics of the community. Taxonomic indicators (density, species density, Shannon diversity and biomass) were calculated using PRIMER v.7 (Clarke and Gorley, 2015) and functional indicators (functional diversity, functional richness, functional evenness, and functional dispersion) were calculated using the R package 'FD' (Laliberte, Legendre \& Shipley, 2015). Table 2 provides a description of the indicators and their interpretation. The functional indicators were weighed using density data, as this data is more 
commonly recorded in benthic impact studies (Hiddink et al., 2017). For completeness, we also provide the results of functional indicators based on biomass data (Supplement - Table S2).

Table 2: Macrofaunal indicators used in the study

\begin{tabular}{|c|c|c|c|c|}
\hline Indicator & Label & Description & $\begin{array}{l}\text { Range } \\
\text { of } \\
\text { values }\end{array}$ & Reference \\
\hline Density & $\mathrm{N}$ & Total number of individuals per sample. & $0-\infty$ & \\
\hline $\begin{array}{l}\text { Species } \\
\text { density }\end{array}$ & $\mathrm{S}$ & Total number of species per sample. & $0-\infty$ & \\
\hline $\begin{array}{l}\text { Shannon } \\
\text { diversity }\end{array}$ & $\mathrm{H}^{\prime}$ & $\begin{array}{l}\text { A measure of taxonomic diversity, which accounts } \\
\text { for } \mathrm{S} \text { and } \mathrm{N} \text {, and the structure (dominance) of a } \\
\text { community. Calculated using } \log _{\mathrm{e}} \text {. }\end{array}$ & $0-\infty$ & $\begin{array}{l}\text { (Shannon, } \\
\text { 1948) }\end{array}$ \\
\hline Log biomass & Biomass & $\begin{array}{l}\text { Total ash free dry weight biomass per sample. } \log _{e} \\
\text { transformed. }\end{array}$ & $0-\infty$ & \\
\hline $\begin{array}{l}\text { Functional } \\
\text { diversity }\end{array}$ & RaoQ & $\begin{array}{l}\text { A measure of trait diversity, which accounts for } \\
\text { trait richness and relative abundance. Rao's } \\
\text { quadratic entropy measures the trait dissimilarity } \\
\text { of two random individuals (akin to Simpson's } \\
\text { diversity). }\end{array}$ & $0-1$ & $\begin{array}{l}\text { (Botta-Dukát, } \\
\text { 2005; Lepš et } \\
\text { al., 2006) }\end{array}$ \\
\hline $\begin{array}{l}\text { Functional } \\
\text { richness }\end{array}$ & Fric & $\begin{array}{l}\text { A measure of the richness of traits expressed in the } \\
\text { community, measured by the total volume of } \\
\text { multivariate trait space occupied by the } \\
\text { community. Calculated using minimum convex } \\
\text { hull. }\end{array}$ & $0-1$ & $\begin{array}{l}\text { (Villéger et al., } \\
\text { 2008) }\end{array}$ \\
\hline $\begin{array}{l}\text { Functional } \\
\text { evenness }\end{array}$ & Feve & $\begin{array}{l}\text { A measure of trait dominance, defined by the } \\
\text { evenness in distribution of trait abundance in } \\
\text { multivariate trait space. Calculated using minimum } \\
\text { convex hull. }\end{array}$ & $0-1$ & $\begin{array}{l}\text { (Villéger et al., } \\
\text { 2008) }\end{array}$ \\
\hline $\begin{array}{l}\text { Functional } \\
\text { dispersion }\end{array}$ & Fdis & $\begin{array}{l}\text { A measure of the average distance of species to the } \\
\text { centre of multivariate trait space. }\end{array}$ & $0-\infty$ & $\begin{array}{l}\text { (Laliberté and } \\
\text { Legendre, } \\
\text { 2010) }\end{array}$ \\
\hline
\end{tabular}

\subsection{Potential recruitment effect on indicators}

The recruitment of benthic macrofauna typically takes place between August and November in the Kattegat. As sampling was conducted in mid-September/early October, there is the risk that newly settled recruits may be recorded in the data. These individuals may consequently have had little or no exposure to trawling, and could potentially bias results. However, recruits would need to settle (or begin ontogenetic development) and reach $\geq 1 \mathrm{~mm}$ in size by the end of September for this to occur. We therefore considered the potential contribution of new recruits to our measures of density (N). Of the most abundant taxa (Table 3), early juveniles of Phoronis sp., Kurtiella bidentata, Nucula nitidosa, Thyasira flexuosa and Scalibregma inflatum, were considered too small or soft bodied to be retained on a $1 \mathrm{~mm}$ sieve at the time of sampling. Moreover, 
early juveniles of these taxa were not observed during the processing of samples. Conversely, Amphiura filiformis and Amphiura chiajei are relatively large macrofaunal taxa and have the potential for rapid postsettlement growth rates (Josefson and Jensen, 1992). Recently settled ( $<1$ year) individuals were also observed in the small fraction during sample processing. We thus estimated the potential growth rate of newly settled Amphiura spp., in accordance with Sköld et al. (2001), to determine if our results could be affected by an influx of Amphiura spp. prior to sampling. The details of these estimates are outlined in the Supplement - Text S1. Accordingly, we took the conservative measure of also removing $50 \%$ of all Amphiura spp. from the dataset, and re-analysing pooled community $\mathrm{N}$ and small fraction $\mathrm{N}$ without these individuals. The results are provided in section 3.4.1.

\subsection{Estimating trawling pressure}

Since 2012, all fishing vessels $\geq 12 \mathrm{~m}$ operating in European Union waters have been required to carry a vessel monitoring system (VMS) receiver on board. VMS receivers collect and send data regarding the vessel location, heading, and speed, with an hourly polling frequency (in Danish and Swedish waters). Raw VMS data were cleaned and filtered to retain only 'trawling activity' (defined as speed ranging between 2 and 4 knots, with a minimum distance of $3 \mathrm{~km}$ from port). These raw data points were then used to reconstruct vessel trawl tracks using cubic Hermite spline interpolation (Hintzen et al., 2012). The tracks were coupled with information on vessel size (from EU logbooks) and gear dimensions (Eigaard et al., 2016) to estimate gear-width, and aggregated to calculate the area of seabed 'swept' during each logbook trip. Trawling effort and swept areas were estimated using the VMStools package (Hintzen et al., 2012). The total swept areas (for all Danish and Swedish $\geq 12 \mathrm{~m}$ vessels and trips) were aggregated within a $1 \mathrm{~km}$ radius around each benthic sampling site. This spatial scale represents a trade-off between precision limitations in i) VMS-positioning, ii) gear position in relation to vessel position, and iii) interpolation of trawl tracks. With the choice of a $1 \mathrm{~km}$ radius, trawling would tend to be randomly distributed within years and uniformly spread on longer timescales (Amoroso et al., 2018; Ellis et al., 2014), and the potential error associated with the spline interpolations is likely to be limited (Lambert et al., 2012). Trawling intensity is described as swept-area ratio (SAR) values, defined as the accumulated swept area within a circle divided by the size of the circle. SAR can therefore be interpreted as the number of times the seabed within the circle is trawled within the given time period. To account for inter-annual variation in trawling activity at infrequently fished sampling sites, and due to the focus of the analysis on larger, longer-lived, macrofauna, SAR estimates were based on three years of fishing effort. Trawling intensity was back-calculated from the day prior to sampling for each replicate sample (September/October 2013 to September/October 2016). 


\subsection{Environmental drivers}

The structure and composition of benthic communities are known to be closely linked to ambient environmental conditions. To account for key natural drivers, and ascertain potentially confounding effects, we included six environmental parameters in addition to trawling intensity. Depth (in situ), LOI\%, and mud\% (described above) were collected in the field. Hydrodynamic data in the form of bottom current velocity $(\mathrm{m} / \mathrm{s})$, bottom temperature $\left({ }^{\circ} \mathrm{C}\right)$, and minimum bottom salinity (PSU), were extracted from the highresolution Kiel Baltic Sea Ice-Ocean Model (BSIOM) (Lehmann et al., 2014) (further information can be found in the Supplement - Text S2). Hydrodynamic data were back-calculated at a monthly scale and averaged over the year prior to sampling (September 2015 - September 2016). The same environmental data values were applied to each replicate with a site. To investigate comparability of environmental conditions across sampling sites, an analysis of similarity was undertaken by multivariate clustering analysis, using the package PRIMER v.7 (Clarke and Gorley, 2015). Clustering was based on normalised Euclidean distances and significance was determined using the SIMPROF routine, which tests for statistically significant station clusters. The analysis resulted in one single cluster of similar habitat characteristics (Supplement - Figure S1). Tests for collinearity between predictors are discussed below.

\subsection{Statistical approach}

We used generalised linear mixed models (GLMMs) to test the ability of macrofaunal indicators to detect trawling impacts across size fractions. As each replicate sample represented an observation, we analysed the data using mixed effects models. This modelling approach is particularly suitable to quantify potential correlations in repeated measure designs (i.e. replicate samples nested within sites) (Bolker et al., 2009). 'Sampling site' was therefore included as a random effect term to account for non-independence of samples, while all other predictors were included as fixed effect terms. The exception to this was for models which contained species density (S) as a response variable. In such cases density (N) was included an additional predictor, as per Gislason et al., (2017) and Sköld et al., (2018). This step was taken to account for changes in the detection rate new species as abundance increases (Gotelli and Colwell, 2001), and therefore improve our ability to detect the effects of other predictors, aside from N. Indicators were modelled using either a negative binomial, Poisson, or Gaussian distribution depending on the data type (count/discrete or continuous). The response variable Biomass was log transformed. To avoid issues related to multicollinearity of predictor variables, pair-wise correlations between the predictor variables were determined. Predictors with correlation coefficients $>0.7$ were excluded from the analysis (Dormann et al, 2013). As a result, LOI\% was removed due to a high correlation with mud\% $(R=0.95, p=<0.001)$. Pairwise correlation coefficients were visualised using the corrplot package (Wei and Simko, 2016) and are presented in the Supplement - 
Figure S2. Variance inflation factor (VIF) values were checked in a model of the remaining predictor variables (Fox and Weisberg, 2011). VIF values for all predictor variables were $<2$. GLMMs were fit using the gImmTMB package (Brooks et al., 2017). To determine the best fit model for each indicator, we used the MuMin package (Barton, 2013) to calculate all possible combinations of the predictor variables. The routine returns all submodels in ascending order based on small-sample size corrected Akaike information criterion (AICC) value. The most parsimonious models were selected based on the lowest AICc (Burnham and Anderson, 2004). To deal with potential difficulties associated with model validation of mixed models, we applied a quantitative (simulation) based approach for determining model diagnostics using the DHARMa package (Hartig, 2016). Marginal effects of GLMMs were plotted using the sjPlot package (Lüdecke, 2016). All analyses were conducted using R version 3.5.0 (R Development Core Team, 2018).

\section{Results}

\subsection{Dataset description}

The study identified 30,783 individuals across 285 different taxa. Of these, 276 (97\%) were identified to species level, $7(2 \%)$ to genus, $1(<1 \%)$ to class, and $1(<1 \%)$ to phylum. Out of the total number of taxa recorded, 91\% were represented in the small fraction (268 taxa), 52\% represented in the large fraction (147 taxa), and $26 \%$ were unique to the large fraction (74 taxa). The dominant taxa in the pooled community were Amphiura filiformis (Class Ophiuroidea), Phoronis sp. (Phylum Phoronida ), Kurtiella bidentata, Nucula nitidosa, Thyasira flexuosa, Eunucula tenuis, Abra nitida (Class Bivalvia), Scalibregma inflatum, Diplocirrus glaucus, Spiophanes kroyeri, Rhodine gracilior, Prionospio fallax, Scoloplos armiger, Pholoe inornata (Class Polychaeta), and Hyala vitrea (Class Gastropoda) (Table 3). A similar group of dominant taxa, and relative contributions to total density, were observed in the small fraction, indicating the importance of this fraction to the overall community. The relative contribution of dominant taxa in the large fraction was greater than in the other size categories, with the top 15 taxa contributing $89 \%$ of total density (Table 3). The dominant taxa in the large fraction also included Amphiura chiajei and Ophiura spp. (Class Ophiuroidea), Maldane sarsi, Terebellides stroemii, Praxillella praetermissa (Class Polychaeta), Turritella communis (Class Gastropoda), and Echinocardium cordatum (Class Echinoidea).

\subsection{Trawling effort}

Over the three year period, fishing intensity (SAR) ranged from 0 to 43.4 (equivalent to $14.5 \mathrm{yr}^{-1}$ ). Sites 3, 5 and 6 (northern Kattegat), and Sites 17 and 19 (south east Læs $\varnothing$ ) were subject to the highest fishing intensities. Untrawled conditions were observed in the closed areas (Sites $45,49,51$ ), and low SAR values 
were observed at various locations across the study area, particularly at Sites $8,12,24$, and 41 . Figure 2 illustrates the relative abundance of the dominant taxa as a function of trawling intensity. The polychaetes Anobothrus gracilis, P. fallax, S. inflatum, and the unrelated horseshoe worm Phoronis sp., were observed in relatively high densities at the untrawled and lightly trawled sites (left of the plot), while being either absent or observed at low densities in the highly trawled sites (right of the plot). This same pattern was also observed for the bivalve species $T$. flexuosa and $N$. nitidosa. Conversely, A. filiformis and $K$. bidentata were recorded at high densities across the range of trawling intensity, while numbers of $D$. glaucus were also relatively consistent. The tubicolous polychaete $S$. kroyeri were observed to peak in numbers at intermediate levels of trawling, while $H$. vitrea occurred in relatively high densities at the most heavily trawled sites. Summary information of site-by-site SAR values and macrofaunal counts are provided in the Supplement - Table S1. 
Table 3: Dominant macrofauna (based on density) of the pooled community, small fraction, and large fractions

\begin{tabular}{|c|c|c|c|c|c|}
\hline \multicolumn{2}{|l|}{ Pooled community } & \multicolumn{2}{|l|}{ Small fraction (1-4mm) } & \multicolumn{2}{|l|}{ Large fraction $(>4 \mathrm{~mm})$} \\
\hline Taxa & \begin{tabular}{|l|} 
Density \\
(cumulative contribution \%)
\end{tabular} & Taxa & $\begin{array}{l}\text { Density } \\
\text { (cumulative contribution \%) }\end{array}$ & Taxa & $\begin{array}{l}\text { Density } \\
\text { (cumulative contribution \%) }\end{array}$ \\
\hline Amphiura filiformis & $8153(26 \%)$ & Amphiura filiformis & $5358(22 \%)$ & Amphiura filiformis & 2795 (41\%) \\
\hline Phoronis sp. & $3942(38 \%)$ & Kurtiella bidentata & $3729(37 \%)$ & Phoronis sp. & $1498(62 \%)$ \\
\hline Kurtiella bidentata & $3729(50 \%)$ & Phoronis sp. & $2444(46 \%)$ & Spiophanes kroyeri & $364(68 \%)$ \\
\hline Nucula nitidosa & $1370(54 \%)$ & Nucula nitidosa & $1192(51 \%)$ & Rhodine gracilior & $343(72 \%)$ \\
\hline Thyasira flexuosa & $1110(58 \%)$ & Scalibregma inflatum & $1062(55 \%)$ & Amphiura chiajei & $202(75 \%)$ \\
\hline Scalibregma inflatum & $1068(61 \%)$ & Thyasira flexuosa & $1015(59 \%)$ & Nucula nitidosa & $178(78 \%)$ \\
\hline Hyala vitrea & $749(63 \%)$ & Hyala vitrea & $749(62 \%)$ & Turritella communis & $124(80 \%)$ \\
\hline Diplocirrus glaucus & $732(66 \%)$ & Diplocirrus glaucus & $725(65 \%)$ & Ophiura sp. & $113(81 \%)$ \\
\hline Spiophanes kroyeri & $611(68 \%)$ & Ennucula tenuis & $540(68 \%)$ & Maldane sarsi & $100(83 \%)$ \\
\hline Ennucula tenuis & $550(69 \%)$ & Pholoe inornata & 497 (70\%) & Thyasira flexuosa & $95(84 \%)$ \\
\hline Rhodine gracilior & $527(71 \%)$ & Prionospio fallax & $493(72 \%)$ & Anobothrus gracilis & $87(86 \%)$ \\
\hline Prionospio fallax & $504(72 \%)$ & Scoloplos armiger & $489(73 \%)$ & Terebellides stroemii & $56(86 \%)$ \\
\hline Scoloplos armiger & $503(74 \%)$ & Abra nitida & $362(75 \%)$ & Abra nitida & $54(87 \%)$ \\
\hline Pholoe inornata & $499(76 \%)$ & Anobothrus gracilis & $303(76 \%)$ & Praxillella praetermissa & $52(88 \%)$ \\
\hline Abra nitida & $416(77 \%)$ & Cylichna cylindracea & $303(77 \%)$ & Echinocardium cordatum & $51(89 \%)$ \\
\hline Pooled community total & 30,783 & Small fraction total & 23,996 & Large fraction total & 6,787 \\
\hline
\end{tabular}




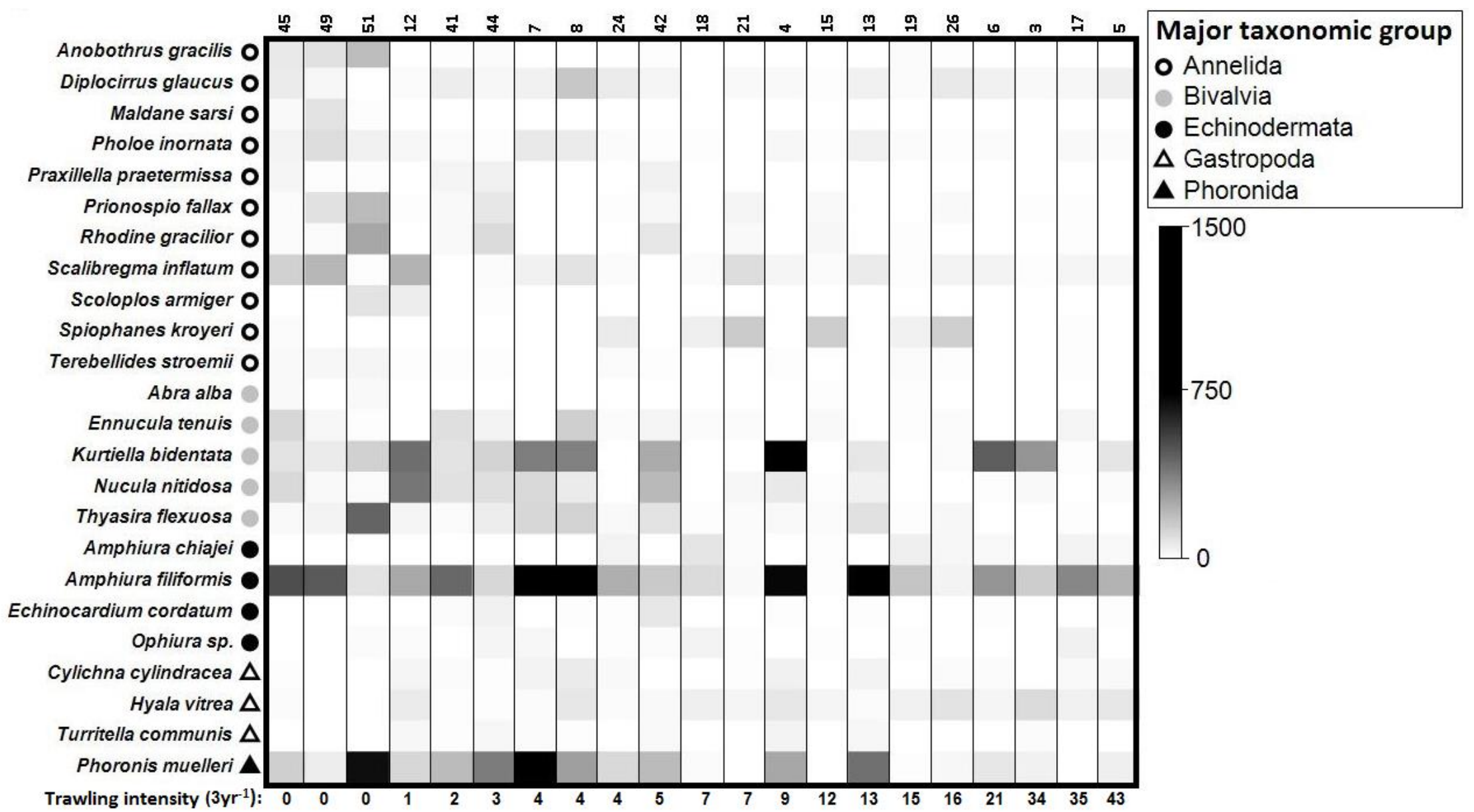

Figure 2: Relative density of dominant fauna across the gradient of trawling intensity, illustrated as a shade plot. Dark shading indicates high density, light shading indicates low density, and values represent the total density of macrofauna per site (or per $0.4 \mathrm{~m}^{2}$ ). SAR values are based on three years of trawling effort $\left(3 \mathrm{yr}^{-1}\right)$, and increase from left to right (bottom of the plot). Sampling site numbers are provided at top of the plot. 


\subsection{Response of macrofaunal indicators to trawling}

Macrofaunal indicators based on the pooled community demonstrated a varied performance, with four of the eight indicators exhibiting a significant negative response to trawling. These included density (N), biomass, functional richness (Fric), and functional dispersion (Fdis) (Table 4). Although species density (S), Shannon diversity $\left(H^{\prime}\right)$, functional diversity (RaoQ) also showed a tendency to decline over the gradient of trawling intensity (Figure 3), these relationships were not statistically significant. On the contrary, functional evenness (Feve) slightly increased over the trawling gradient, although again this trend was not significant. In the small fraction, none of the taxonomic based indicators ( $N, \mathrm{~S}, \mathrm{H}^{\prime}$, biomass) responded to trawling, whereas two of the functional indicators (Fric and Fdis) demonstrated significant negative relationships with trawling. These indicators were distinctive, in that they demonstrated significant negative relationships with trawling intensity across all size categories. In the large fraction, each of the eight indicators examined declined significantly with trawling. Moreover, trawling was the sole explanatory variable in the most parsimonious models of $\mathrm{S}, \mathrm{H}^{\prime}$, Fric, Feve, and Fdisp. Comparison of model parameter estimates across size fractions indicates that there was also a larger effect of trawling per unit N, biomass, RaoQ and Fdisp, in the large fraction. Results for the functional indicators calculated using biomass data are presented in Table S2, and in general, these indicators performed similarly to their density-based counterparts. The main discrepancies being that Fdis (pooled community) showed no relationship with trawling, and RaoQ (small fraction) responded to negatively to trawling. 
Table 4: Summary output for generalised linear mixed models of macrofaunal indicators. The values shown are parameter estimates, and associated standard error (shown in brackets). The significance level is denoted by asterisks $\left(^{*}=\mathrm{P}<0.05 ; * *=\mathrm{P}<0.01 ; * * *=\mathrm{P}<0.001\right)$. Conditional $\mathrm{R}^{2}$ values describe the proportion of variance explained by both the fixed and random terms.

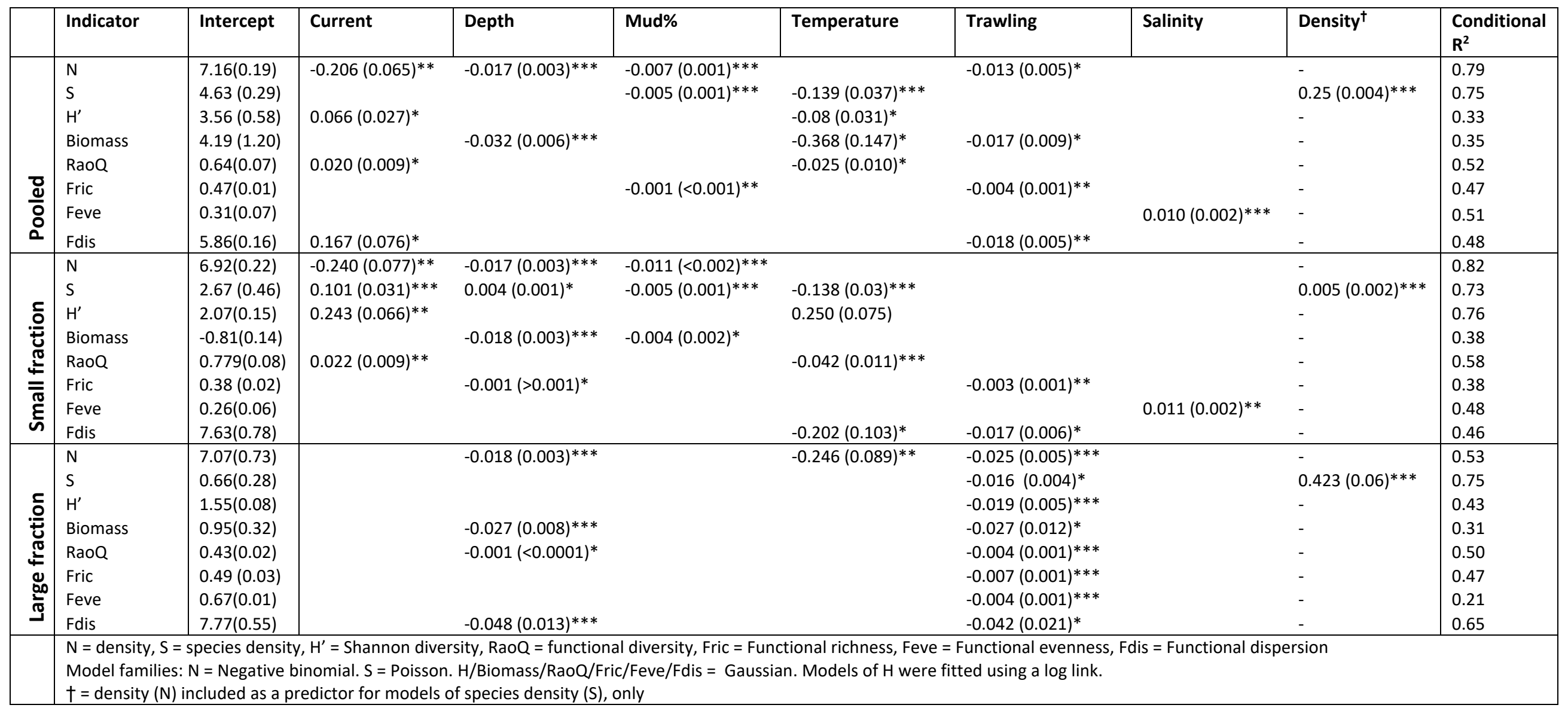



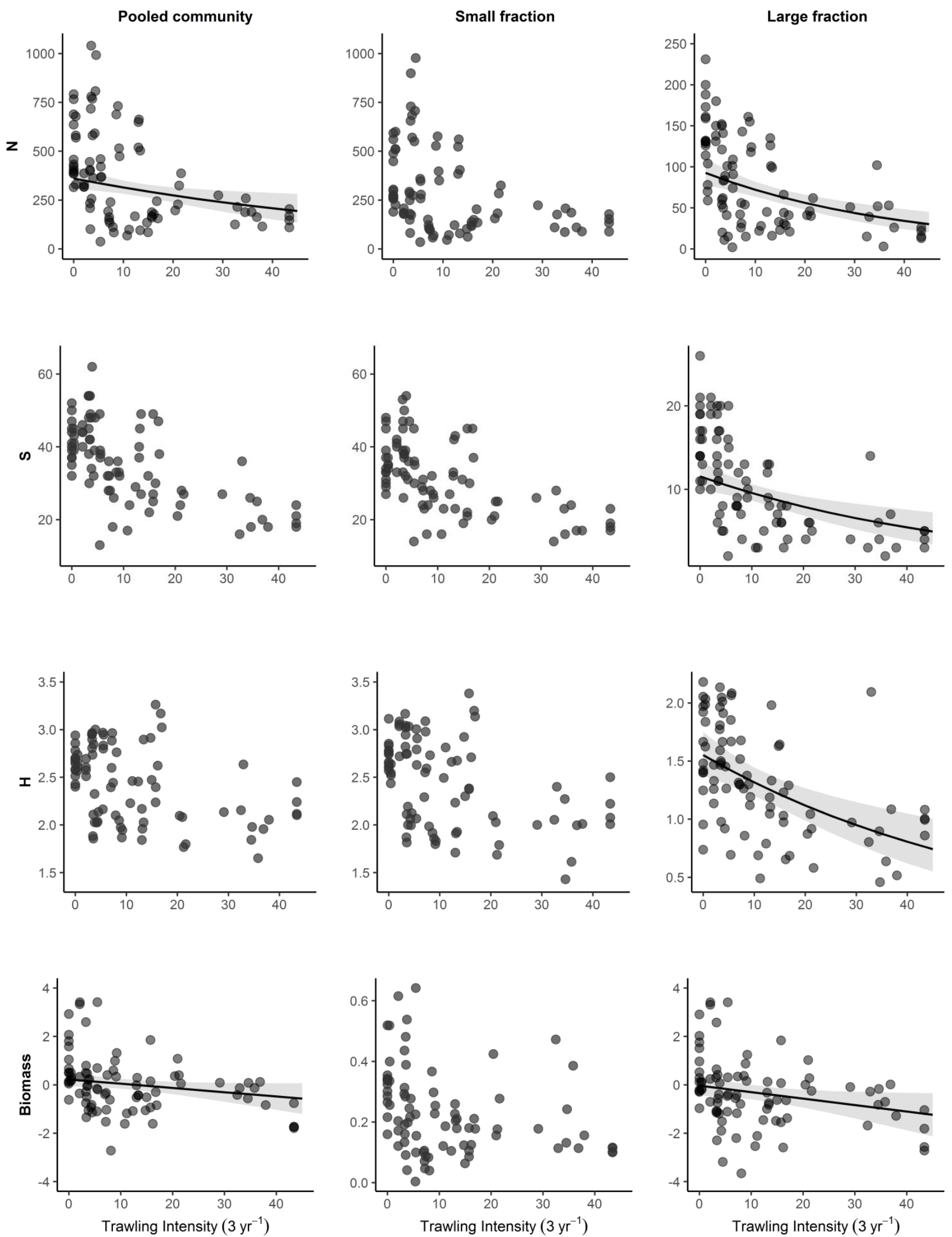

Continued... 

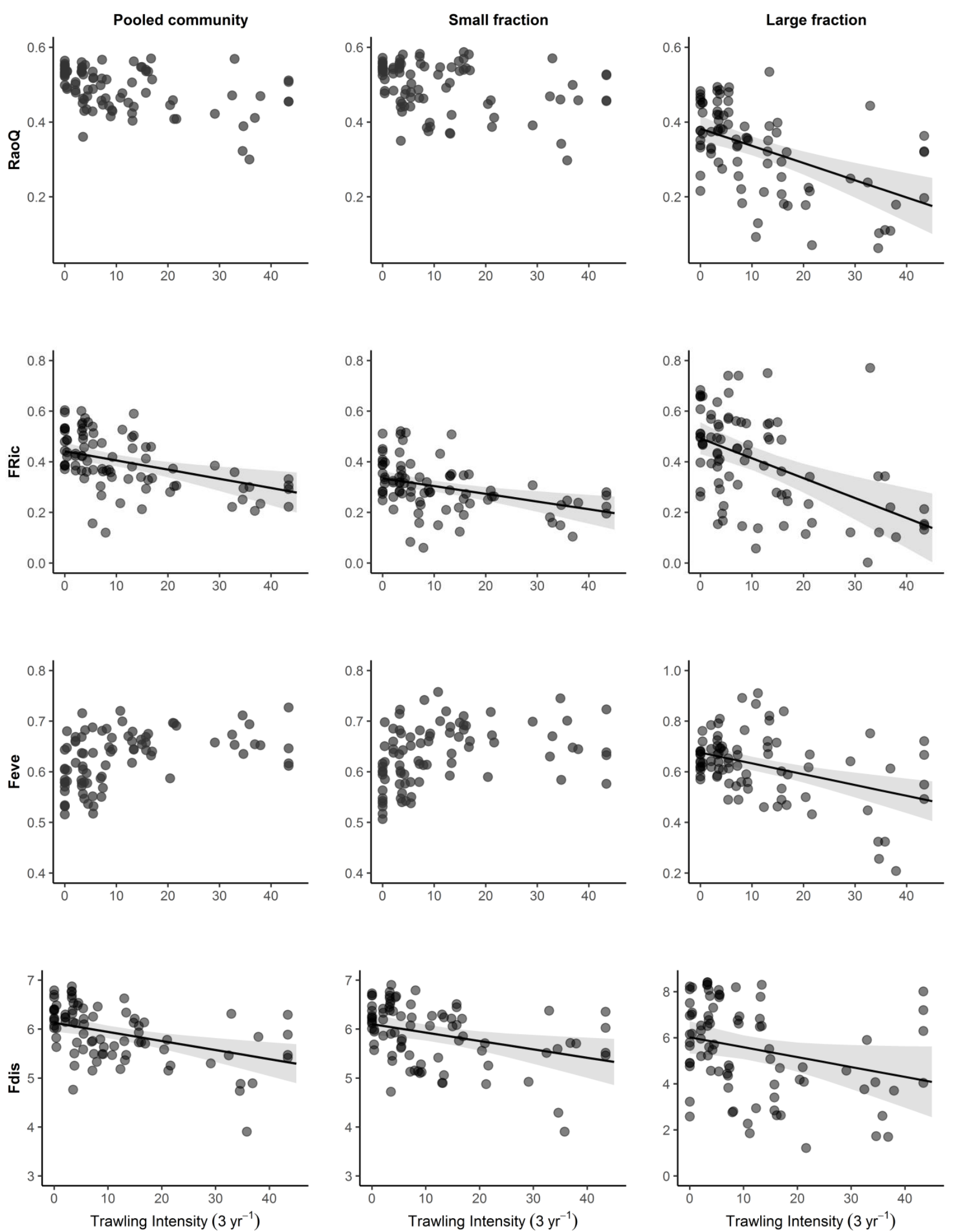

Figure 3: Relationships between trawling intensity and macrofaunal indicators derived from the pooled, small, and large fractions, respectively. Regression lines represent the predicted values from GLMMs 
presented in Table 4. Greyed area represent $95 \%$ confidence intervals. The raw observations are overlaid as data points. Note: $\mathrm{Y}$-axis scale differs in large fraction plots, with the exception of biomass, RaoQ, and Fric.

\subsection{Response to environmental drivers}

Overall, the indicators based on the pooled community and small fraction were strongly influenced by environmental drivers. A number of significant relationships were observed between indicators and current speed (mainly positive relationships) and temperature (mainly negative relationships) in both these categories, while depth was more prominent in the small fraction. Salinity was observed to be a poor predictor overall (pooled, small and large fractions), with Feve being the only indicator to respond to salinity. The overall influence of environmental drivers on large fraction indicators was considerably less. The large fraction indicators of $\mathrm{N}$, biomass, RaoQ, and Fdis responded significantly to depth, while $\mathrm{N}$ also responded to temperature.

\subsubsection{Potential effect of recruits on abundance}

Based on estimates provided by Sköld et al. (2001), the post-metamorphic settlers of Amphiura spp. would be expected to be $0.4-0.5 \mathrm{~mm}$ in diameter. In the event of an early settlement from August onwards, and a daily increase in disk diameter of $0.42 \%$ and arm length of $1.76 \%$, individual Amphiura spp. would thus need a minimum of 75 days to reach $\geq 1 \mathrm{~mm}$ in diameter. As data collection was completed $\sim 65$ days after the beginning of August, it was deemed unlikely that many recruits would have reached $\geq 1 \mathrm{~mm}$ by the time of sampling. Furthermore, empirical evidence of Sköld et al 2001 also show that the vast majority of Amphiura spp. sampled in early October in the Kattegat were $<1 \mathrm{~mm}$ in length. Nevertheless, the precautionary step to exclude $50 \%$ of Amphiura spp. individuals from pooled community $\mathrm{N}$ and small fraction $\mathrm{N}$ did not change the overall outcome. , The model for $\mathrm{N}$ minus 50\% Amphiura spp. included trawling $(\beta=-0.017$, se $=0.004, \mathrm{p}=$ $<0.001)$, Mud\% ( $\beta=-0.006$, se $=0.001, p=<0.001)$, depth $(\beta=-0.02$, se $=0.001, p=<0.001)$, and current $(\beta$ $=-0.117$, se $=0.05, p=0.002$ ). Likewise, the model for small fraction $\mathrm{N}$ minus $50 \%$ Amphiura spp. included $\operatorname{Mud\% }(\beta=0.01$, se $=0.002, p=<0.001)$, depth $(\beta=0.017$, se $=0.003 p=<0.001)$, and current $(\beta=-0.188$, se $=0.07, p=0.009$ ). The conditional $R^{2}$ for these models were 0.77 and 0.81 , respectively. Although spring sampling would have been optimal (logistical constraints did not allow for this), the retrospective steps taken to validate our results demonstrate that recruitment effects are unlikely to have affected our results. Furthermore, we provide the results of biomass and biomass based indicators, which are less likely to be affected by recent recruitment events. 


\section{Discussion}

In this analysis we describe and compare the ability of eight ecological indicators to detect trawling impacts across macrofaunal size categories. Our results suggest that benthos display a size-dependent sensitivity to trawling, whereby large fauna $(\geq 4 \mathrm{~mm})$ and their associated traits are most affected. Indicators derived from large fauna were able to capture this sensitivity, effectively detect trawling disturbance, while being less affected by other environmental drivers. Studies which apply macrofaunal indicators to assess human and natural pressures in the marine environment are typically undertaken using indicators based on all members of the benthic community (equivalent of the pooled community in this study). This approach may therefore not be the most suitable for the assessment of trawling impacts to benthic communities. In the following sections, we discuss the performance of indicators, as well as the ecological and management implications of these findings.

\subsection{Response of pooled community indicators to trawling}

The community-level indicators of density $(\mathrm{N})$, biomass, functional richness (Fric), and functional dispersion (Fdis) declined significantly with increasing trawling disturbance in our study. Under chronic trawling conditions, rates for the depletion of biota (density and biomass combined) have been estimated at $6 \%$ per pass of an otter trawl (Hiddink et al., 2017). As the most heavily fished sites in this study were associated with SAR values of up to 43.4 over a three year period (or $\sim 14.5 \mathrm{yr}^{-1}$ ), $\mathrm{N}$ and biomass would be expected to considerably decline in heavily trawled areas. In general, declines in these indicators will occur when the fishery exerts mortality rates higher than what can be replaced by the wider population, either through recruitment or potentially immigration. Although this rate may vary between location, the efficacy of $\mathrm{N}$ as indicator of trawling impacts in gradient studies has been demonstrated in a number of regions, including in the Kattegat (Gislason et al., 2017), Irish Sea (Hinz et al., 2009), Mediterranean (Mangano et al., 2014), and New Zealand (Thrush et al., 1998). Equally, biomass has been shown to be an effective indicator of trawling disturbance. Repeated and intense trawling will typically result in shifts from communities dominated by high biomass taxa, to those dominated by highly abundant small macrofauna (Hiddink et al., 2006; Jennings et al., 2002; Kaiser et al., 2000). Furthermore, total biomass has been shown to persistently decline in highly trawled areas, even when other indicators (such as N) have become unresponsive (Reiss et al., 2009). Despite this, the performance of $\mathrm{N}$ and biomass can also vary across studies. A good example of this is provided by Sköld et al., (2018). This study was undertaken in nearby Nephrops grounds, and across a similar gradient of trawling intensity (up to $15.8 \mathrm{yr}^{-1}$ ), yet did not detect significant shifts in $\mathrm{N}$ or biomass. A possible explanation is that the models used in their study were characterised by high uncertainty at the heavily fished sites (due to relatively few observations), which may have affected overall trends. Furthermore, samples were collected 
from long-standing monitoring sites, while our data are based on a 'snapshot' sampling event. While our approach has the disadvantage of lacking information on inter-annual trends, it does allow for the sampling design to be tailored to the observed range of recent trawling effort, while accounting for effort across other environmental factors, such as depth. Aside from these differences, Sköld et al., (2018) also observed that the density of Amphiura chiajei, a particularly dominant taxa in their dataset, showed a positive relationship with trawling. This may demonstrate that when a community is dominated by 'robust' taxa, their response has the potential to mask that of the remaining community. By contrast, abundances of Amphiura spp. (mostly A. filiformis, but also A. chiajei) were relatively stable over the trawling gradient in our study (Figure 2), while taxa which increased over the trawling gradient (e.g. Hyala vitrea) contributed less to total abundance. Moreover, taxa such as $H$. vitrea were completely absent from the large fraction, and may partly explain the clearer trends observed in this size category (discussed in section 4.2). Observations from Nephrops grounds in the Irish Sea have conversely shown A. filiformis to be highly sensitive to trawling (Queirós et al., 2006; Hinz et al., 2009). While the exact reasons for these discrepancies are unclear, it is possible that local sedimentary and hydrodynamic conditions may affect the relationship between some taxa and trawling.

Although species density and diversity ( $\mathrm{S}$ and $\mathrm{H}^{\prime}$ ) showed a negative relationship with trawling in our study, these relationships were not significant. This lack of response is in agreement with other trawling gradient studies (Ball et al., 2000; Currie et al., 2011; Reiss et al., 2009), and may add weight to general concerns about their suitability in ecological monitoring. Measures of species richness can be highly sensitive to factors such as the size of sampling area, sampling intensity, and taxonomic properties of the species in question (Fleishman et al., 2006). A further complicating factor is that species density is often positively correlated with density (Gislason et al., 2017; Gotelli and Colwell, 2001). To account for observed variation in N between our sampling stations, we included $\mathrm{N}$ as a predictor for models of $\mathrm{S}$. Although this step allows for a more accurate assessment of the role of other predictors, this did not result in the detection of trawling. Nonetheless, this relationship between $\mathrm{N}$ and $\mathrm{S}$ is theoretically relevant for all indicators derived from estimates of species richness, such as diversity measures (e.g. Shannon-diversity, functional diversity), and for multi-metric indicators commonly used in national benthic monitoring programs. Currently, most diversity indicators are applied without accounting for this relationship, or by e.g. using rarefied species richness. For this reason we did not attempt to standardize our diversity indicators with respect to $\mathrm{N}$, but followed common practice, and future work is needed to quantify the effect of this relationship and its relevance for indicator use. 
Our study also tested the performance of several functional indicators, which provide alternative and complimentary information to taxonomic measures. Trawling has been shown to negatively affect trait composition, and characteristics such as the size, age, nutrient cycling, and trophic profile of benthic communities (Bolam et al., 2017; Bremner et al., 2003; Tillin et al., 2006). Nonetheless, comparatively few studies have formally tested the ability of functional indicators to reflect these changes. In contrast to measures of species density and diversity, functional richness (Fric) and functional dispersion (Fdis) demonstrated significant negative relationships with trawling, doing so across all size categories. Fric is largely influenced by the loss or addition of unique traits, while Fdis provides a measure of the distinctiveness of traits within the community. The results thus suggest that trawling may have a greater effect on trait richness/diversity than on taxonomic counterparts. If that were the case, then communities in heavily trawled areas may become functionally impoverished, while a base level of species diversity may be comparatively unaffected. This would have implications for the functionality of benthic communities across fishing grounds, and suggests that monitoring of functional indicators should be undertaken in conjunction with taxonomic approaches.

\subsection{Response of large and small fraction indicators to trawling}

It has been suggested that the body-size composition of a community can provide a proxy for a large degree of embedded ecological information, such as ecological quality and sensitivity to disturbance (Woodward et al., 2005). This is supported by our results, where each of the indicators derived from the large size fraction displayed significant negative relationships with trawling. Although previous studies have investigated trawling impacts to large epifauna (Hinz et al., 2009), and the production rates of large macrofauna ( $\geq 4 \mathrm{~mm}$ ) (Reiss et al., 2009), none have explicitly tested community indicators based on body-size. Accordingly, the results of this study are not readily comparable to others, although the processes which underpin the sensitivity of large fauna are relatively well described. While, some large-bodied taxa are comparatively unaffected by trawling, due to e.g. burrowing depth, high mobility, or robust physical structure, populations of larger fauna are unable to withstand the high rates of mortality imposed by chronic trawling (Duplisea et al., 2002). Consequently, trawling leads to the disproportionate loss of large individuals, and an associated steepening in the slope of the size spectrum (Jennings et al., 2001; Queirós et al., 2006). The effects of trawling on large fauna is also thought to be greater than that of other influential environmental factors, such as depth and sediment characteristics (Duplisea et al., 2002), and may explain the reduced influence of natural drivers to indicators based on this size fraction. By the time an individual is near its asymptotic size, ambient environmental conditions will have selected for certain species or traits. Large fauna may therefore be less susceptible to variation caused by natural processes and local recruitment success, which are known 
to complicate the outcome of trawling impact assessments, and may be better suited to track trawling impacts over time and space. Furthermore, large fauna are considerably less abundant than small fauna, meaning that fewer individuals and species are required for analysis and monitoring. Overall, indicators derived from the small fraction were less responsive to trawling, and demonstrated several significant relationships with environmental drivers such as depth, current speed, mud content, and temperature. Small macrofauna typically exhibit higher growth rates, earlier reproductive onset, wide-spread recruitment, and elevated abundances of small fauna have been shown to be effective indicators of other environmental pressures, such as nutrient enrichment (Pearson and Rosenberg, 1978). Nevertheless, trawling is thought to reduce community abundance and biomass across a range of benthic size classes (Hinz et al., 2008), and may explain why proliferations of opportunistic species have not been observed in highly trawled area (Hinz et al., 2009; Jennings et al., 2001). While indicators based on small fauna were relatively unresponsive in our study, individual taxa (and traits) within this fraction may be potentially affected by trawling. A more detailed size-based investigation of species and trait-level responses would therefore help to clarify potential relationships. Such results may also be relevant for less productive areas, where comparatively lower abundances and biomass of large fauna may reduce the effectiveness of large community indicators. Regardless, the varying responses observed between the two size fractions highlight an underlying issue with using pooled community indicators to detect trawling impacts. This is as species, taxonomic groups, and traits may display contradictory responses to trawling and to other environmental drivers.

\subsection{Ecological implications}

The ecosystem effects of trawling can range from changes in the functioning of marine sediments (Sciberras et al., 2016), to bottom-up interactions with higher trophic levels (Eddy et al., 2017; Hiddink et al., 2011; Hinz et al., 2017). The results of this study provide additional evidence that chronic trawling has a strong negative effect on the abundance (i.e. density and biomass) (see Hiddink et al., 2017; Sciberras et al., 2018) and functional capacity of benthic macrofaunal communities (see Bremner et al., 2003; de Juan et al., 2007; Tillin et al., 2006), while demonstrating the value of closed areas to scientific studies of demersal fishing. In particular, we show that highly trawled communities are associated with significant reductions in large macrofauna, and their associated traits. Large macrofauna play a particularly important role in several benthic processes, and it is thought that their importance in nutrient cycling is such that losses cannot be replicated, or offset, by smaller species (Solan et al., 2004). Manipulative experiments have shown that the removal of large individuals from intertidal communities have significant negative effects on local sedimentary characteristics, biogeochemical fluxes, and community dominance structures (Thrush et al., 2006). In addition, variation in intraspecific size has been recognised as a stronger predictor of ecosystem 
function than that of density or species density (Norkko et al., 2013). Theoretical and empirical evidence would therefore suggest that the loss of large fauna may have significant consequences for the functionality of benthic communities. The role and decline of large fauna from wider ecological systems has received increased attention in recent years (see Malhi et al., 2016), yet the significance of this for benthic systems across fishing grounds is poorly understood.

\subsection{Conclusions and applications}

Using a whole community approach, four of the eight macrofaunal indicators examined were unable to detect trawling impacts. By contrast, all indicators based on large macrofauna responded consistently and effectively to trawling intensity. These results were demonstrated using data from a one-off sampling event, and in an area where fisheries may have altered the benthic community over time (Josefson et al., 2018). Although this approach cannot be retrospectively applied to existing data, our findings may have implications for future ecological monitoring of bottom trawling activities. By size-separating the benthic community, improved indicator performance was achieved from a numerically reduced subset, comprising some $22 \%$ of all individuals and $52 \%$ of taxa. The laboratory based processing of macrofaunal samples is a labour intensive and costly task. Considering this, we estimate that the time taken to screen the whole community (i.e. pick all biota from the sieved residuum), and taxonomically identify and determine biomass just for the large fraction, would have reduced the total laboratory processing time by approximately $75 \%$. This time difference is mainly due to the fewer individuals and species requiring identification. The approach outlined in this study is easily employed, does not require prior ecological knowledge of the system, and future work should seek to test its application across different habitat types and geographic regions. We suggest that this, along with other promising methodologies (Hiddink et al., 2018; Rijnsdorp et al., 2018), have the potential to provide a suite of improved tools to better detect, assess, and monitor bottom trawling impacts on benthic communities.

\section{Acknowledgements}

We thank the captains and crew of the DTU Aqua RV Havfisken: Aage Thaarup, Rene Nyholm Erlandsen, Søren Larsen Grønby and Jens Holm, and Eva Maria F. Pedersen and Martin Veicherts for assistance during fieldwork. Thanks to Annegrete D. Hansen and Louse Louise Scherffenberg Lundgaard for assistance with laboratory work, and to Andreas Vratsistas, Irene Saez Devis, Liv Dramsh øj and Miguel Martin for assistance in sorting benthic samples into higher taxonomic groups. We thank Tobias Mildenberger and Alexandros Kokkalis for assistance regarding data analysis. We also thank the anonymous reviewers for their time and helpful suggestions to improve the manuscript. The work was funded by The Danish Fisheries Agency, 
Ministry of Environment and Food of Denmark, through the European Maritime and Fisheries Fund (EMFF) via the project "Udvikling af bæredygtig forvaltning af følsomme habitater og arter i Kattegat" (grant agreement number 33113-B-16-024) and DTU Aqua.

\section{Supplementary information}

[See supplement]

\section{References}

Al-Hamdani, Z.K., Reker, J., Leth, J.O., Reijonen, A., Kotilainen, A.T., Dinesen, G.E., 2007. Development of marine landscape maps for the Baltic Sea and the Kattegat using geophysical and hydrographical parameters. Geol. Surv. Denmark Greenl. Bull. 13, 61-64.

Amoroso, R.O., Pitcher, C.R., Rijnsdorp, A.D., McConnaughey, R.A., Parma, A.M., Suuronen, P., Eigaard, O.R., Bastardie, F., Hintzen, N.T., Althaus, F., Baird, S.J., Black, J., Buhl-Mortensen, L., Campbell, A.B., Catarino, R., Collie, J., Cowan, J.H., Durholtz, D., Engstrom, N., Fairweather, T.P., Fock, H.O., Ford, R., Gálvez, P.A., Gerritsen, H., Góngora, M.E., González, J.A., Hiddink, J.G., Hughes, K.M., Intelmann, S.S., Jenkins, C., Jonsson, P., Kainge, P., Kangas, M., Kathena, J.N., Kavadas, S., Leslie, R.W., Lewis, S.G., Lundy, M., Makin, D., Martin, J., Mazor, T., Gonzalez-Mirelis, G., Newman, S.J., Papadopoulou, N., Posen, P.E., Rochester, W., Russo, T., Sala, A., Semmens, J.M., Silva, C., Tsolos, A., Vanelslander, B., Wakefield, C.B., Wood, B.A., Hilborn, R., Kaiser, M.J., Jennings, S., 2018. Bottom trawl fishing footprints on the world's continental shelves. Proc. Natl. Acad. Sci. 201802379. https://doi.org/10.1073/pnas.1802379115

Anon. 2008. Directive 2008/56/EC of the European Parliament and of the Council of 17 June2008 establishing a framework for community action in the field of marine environmental policy (Marine Strategy Framework Directive)

Anon. 2010. Commission Decision of 1 September 2010 on criteria and methodological standards on good environmental status of marine waters 2010/477/EU

Atkinson, L.J., Field, J.G., Hutchings, L., 2011. Effects of demersal trawling along the west coast of southern Africa: Multivariate analysis of benthic assemblages. Mar. Ecol. Prog. Ser. https://doi.org/10.3354/meps08956

Ball, B.J., Fox, G., Munday, B.W., 2000. Long- and short-term consequences of a Nephrops trawl fishery on the benthos and environment of the Irish Sea. ICES J. Mar. Sci. 57, 1315-1320. https://doi.org/10.1006/jmsc.2000.0924

Barton, K. (2013) MuMIn: Multi-Model Inference. R Package Version 1.40 .4 http://CRAN.Rproject.org/package=MuMIn

Bastardie, F., Nielsen, J.R., Ulrich, C., Egekvist, J., Degel, H., 2010. Detailed mapping of fishing effort and landings by coupling fishing logbooks with satellite-recorded vessel geo-location. Fish. Res. https://doi.org/10.1016/j.fishres.2010.06.016

Begon, M., Harper, J.L., Townsend, C.R., 2006. Ecology: From Individuals to Ecosystems, fourth ed. Blackwell 
Science, Oxford.

Bolam, S.G., Garcia, C., Eggleton, J., Kenny, A.J., Buhl-Mortensen, L., Gonzalez-Mirelis, G., van Kooten, T., Dinesen, G., Hansen, J., Hiddink, J.G., Sciberras, M., Smith, C., Papadopoulou, N., Gumus, A., Van Hoey, G., Eigaard, O.R., Bastardie, F., Rijnsdorp, A.D., 2017. Differences in biological traits composition of benthic assemblages between unimpacted habitats. Mar. Environ. Res. 126, 1-13. https://doi.org/10.1016/j.marenvres.2017.01.004

Bolker, B.M., Brooks, M.E., Clark, C.J., Geange, S.W., Poulsen, J.R., Stevens, M.H.H., White, J.S.S., 2009. Generalized linear mixed models: a practical guide for ecology and evolution. Trends Ecol. Evol. https://doi.org/10.1016/j.tree.2008.10.008

Botta-Dukát, Z., 2005. Rao's quadratic entropy as a measure of functional diversity based on multiple traits. J. Veg. Sci. 16, 533-540. https://doi.org/10.1111/j.1654-1103.2005.tb02393.x

Bremner, J., Frid, C.L.J., Rogers, S.I., 2003. Assessing Marine Ecosystem Health: The long-term effects of fishing on functional biodiversity in North Sea benthos, in: Aquatic Ecosystem Health and Management. https://doi.org/10.1080/14634980301470

Brose, U., Blanchard, J.L., Eklöf, A., Galiana, N., Hartvig, M., R. Hirt, M., Kalinkat, G., Nordström, M.C., O'Gorman, E.J., Rall, B.C., Schneider, F.D., Thébault, E., Jacob, U., 2016. Predicting the consequences of species loss using size-structured biodiversity approaches. Biol. Rev. 49, 684-697. https://doi.org/10.1111/brv.12250

Burnham, K.P., Anderson, D.R., 2004. Multimodel Inference. Sociol. Methods Res. 33, 261-304. https://doi.org/10.1177/0049124104268644

Chevene, F., Doleadec, S., Chessel, D., 1994. A fuzzy coding approach for the analysis of long-term ecological data. Freshw. Biol. 31, 295-309. https://doi.org/10.1111/j.1365-2427.1994.tb01742.x

Clarke KR, Gorley RN (2015) Primer v7:user manual/tutorial. PRIMER-E Ltd, Plymouth. www.primere.com/primer 7 download.htm

Currie, D.R., Dixon, C.D., Roberts, S.D., Hooper, G.E., Sorokin, S.J., Ward, T.M., 2011. Relative importance of environmental gradients and historical trawling effort in determining the composition and distribution of benthic macro-biota in a large inverse estuary. Fish. Res. https://doi.org/10.1016/j.fishres.2010.11.003

de Juan, S., Thrush, S.F., Demestre, M., 2007. Functional changes as indicators of trawling disturbance on a benthic community located in a fishing ground (NW Mediterranean Sea). Mar. Ecol. Prog. Ser. 334, 117-129. https://doi.org/10.3354/meps334117

Diesing, M., Stephens, D., Aldridge, J., 2013. A proposed method for assessing the extent of the seabed significantly affected by demersal fishing in the Greater North Sea. ICES J. Mar. Sci. 70, 1085-1096. https://doi.org/10.1093/icesjms/fst066

Dormann, C.F., Elith, J., Bacher, S., Buchmann, C., Carl, G., Carré, G., Marquéz, J.R.G., Gruber, B., Lafourcade, B., Leitão, P.J., Münkemüller, T., McClean, C., Osborne, P.E., Reineking, B., Schröder, B., Skidmore, A.K., Zurell, 
D., Lautenbach, S., 2013. Collinearity: a review of methods to deal with it and a simulation study evaluating their performance. Ecography (Cop.). 36, 27-46. https://doi.org/10.1111/j.1600-0587.2012.07348.x

Duplisea, D.E., Jennings, S., Warr, K.J., Dinmore, T.A., 2002. A size-based model of the impacts of bottom trawling on benthic community structure. Can. J. Fish. Aquat. Sci. 59, 1785-1795. https://doi.org/10.1139/f02-148

Eddy, T.D., Lotze, H.K., Fulton, E.A., Coll, M., Ainsworth, C.H., de Araújo, J.N., Bulman, C.M., Bundy, A., Christensen, V., Field, J.C., Gribble, N.A., Hasan, M., Mackinson, S., Townsend, H., 2017. Ecosystem effects of invertebrate fisheries. Fish Fish. 18, 40-53. https://doi.org/10.1111/faf.12165

Eigaard, O.R., Bastardie, F., Breen, M., Dinesen, G.E., Hintzen, N.T., Laffargue, P., Mortensen, L.O., Nielsen, J.R., Nilsson, H.C., O’Neill, F.G., Polet, H., Reid, D.G., Sala, A., Sköld, M., Smith, C., Sørensen, T.K., Tully, O., Zengin, M., Rijnsdorp, A.D., 2016. Estimating seabed pressure from demersal trawls, seines, and dredges based on gear design and dimensions. ICES J. Mar. Sci. 73, i27-i43. https://doi.org/10.1093/icesjms/fsv099

Eigaard, O.R., Bastardie, F., Hintzen, N.T., Buhl-Mortensen, L., Buhl-Mortensen, P., Catarino, R., Dinesen, G.E., Egekvist, J., Fock, H.O., Geitner, K., Gerritsen, H.D., González, M.M., Jonsson, P., Kavadas, S., Laffargue, P., Lundy, M., Gonzalez-Mirelis, G., Nielsen, J.R., Papadopoulou, N., Posen, P.E., Pulcinella, J., Russo, T., Sala, A., Silva, C., Smith, C.J., Vanelslander, B., Rijnsdorp, A.D., 2017. The footprint of bottom trawling in European waters: distribution, intensity, and seabed integrity. ICES J. Mar. Sci. J. du Cons. 74, fsw194. https://doi.org/10.1093/icesjms/fsw194

Ellis, N., Pantus, F., Pitcher, C.R., II, T.Q., 2014. Scaling up experimental trawl impact results to fishery management scales - a modelling approach for a "hot time." Can. J. Fish. Aquat. Sci. 71, 733-746. https://doi.org/10.1139/cjfas-2013-0426

FAO (2003) Fisheries management 2: The ecosystem approach to fisheries. FAO Technical Guidelines for Responsible Fisheries (FAO, Rome), 4(Suppl 2):112.

Fleishman, E., Noss, R.F., Noon, B.R., 2006. Utility and limitations of species richness metrics for conservation planning. Ecol. Indic. https://doi.org/10.1016/j.ecolind.2005.07.005

Fox, J., Weisberg, S., 2011. An R Companion to Applied Regression, second edition [WWW Document]. Sage, Thousand Oaks CA.

Frid, C., Paramor, O., Scott, C., 2005. Ecosystem-based fisheries management: Progress in the NE Atlantic. Mar. Policy. https://doi.org/10.1016/j.marpol.2004.07.004

Gilkinson, K., Paulin, M., Hurley, S., Schwinghamer, P., 1998. Impacts of trawl door scouring on infaunal bivalves: Results of a physical trawl door model/dense sand interaction. J. Exp. Mar. Bio. Ecol. https://doi.org/10.1016/\$0022-0981(97)00207-4

Gislason, H., Bastardie, F., Dinesen, G.E., Egekvist, J., Eigaard, O.R., 2017. Lost in translation? Multi-metric macrobenthos indicators and bottom trawling. Ecol. Indic. 82, 260-270. https://doi.org/10.1016/j.ecolind.2017.07.004 
Gotelli, N.J., Colwell, R.K., 2001. Quantifying biodiversity: Procedures and pitfalls in the measurement and comparison of species richness. Ecol. Lett. https://doi.org/10.1046/j.1461-0248.2001.00230.x

Greenstreet, S.P.R., Rogers, S.I., Rice, J.C., Piet, G.J., Guirey, E.J., Fraser, H.M., Fryer, R.J., 2011. Development of the EcoQO for the North Sea fish community. ICES J. Mar. Sci. 68, 1-11. https://doi.org/10.1093/icesjms/fsq156

Hartig, F. (2016). DHARMa: Residual diagnostics for hierarchical (multi-level/mixed) regression models . DHARMa version 0.2.0. URL https://cran.r-project.org/web/packages/DHARMa/index.html.

Hiddink, J.G., Jennings, S., Kaiser, M.J., Queirós, A.M., Duplisea, D.E., Piet, G.J., 2006. Cumulative impacts of seabed trawl disturbance on benthic biomass, production, and species richness in different habitats. Can. J. Fish. Aquat. Sci. 63, 721-736. https://doi.org/10.1139/f05-266

Hiddink, J.G., Jennings, S., Sciberras, M., Bolam, S.G., Cambiè, G., McConnaughey, R.A., Mazor, T., Hilborn, R., Collie, J.S., Pitcher, R., Parma, A.M., Suuronen, P., Kaiser, M.J., Rijnsdorp, A.D., 2018. Assessing bottomtrawling impacts based on the longevity of benthic invertebrates. J. Appl. Ecol. https://doi.org/10.1111/13652664.13278

Hiddink, J.G., Jennings, S., Sciberras, M., Szostek, C.L., Hughes, K.M., Ellis, N., Rijnsdorp, A.D., McConnaughey, R.A., Mazor, T., Hilborn, R., Collie, J.S., Pitcher, C.R., Amoroso, R.O., Parma, A.M., Suuronen, P., Kaiser, M.J., 2017. Global analysis of depletion and recovery of seabed biota after bottom trawling disturbance. Proc. Natl. Acad. Sci. 114, 8301-8306. https://doi.org/10.1073/pnas.1618858114

Hiddink, J.G., Johnson, A.F., Kingham, R., Hinz, H., 2011. Could our fisheries be more productive? Indirect negative effects of bottom trawl fisheries on fish condition. J. Appl. Ecol. https://doi.org/10.1111/j.13652664.2011.02036.x

Hintzen, N.T., Bastardie, F., Beare, D., Piet, G.J., Ulrich, C., Deporte, N., Egekvist, J., Degel, H., 2012. VMStools: Open-source software for the processing, analysis and visualisation of fisheries logbook and VMS data. Fish. Res. 115-116, 31-43. https://doi.org/10.1016/j.fishres.2011.11.007

Hinz, H., Moranta, J., Balestrini, S., Sciberras, M., Pantin, J.R., Monnington, J., Zalewski, A., Kaiser, M.J., Sköld, M., Jonsson, P., Bastardie, F., Hiddink, J.G., 2017. Stable isotopes reveal the effect of trawl fisheries on the diet of commercially exploited species. Sci. Rep. 7, 6334. https://doi.org/10.1038/s41598-017-06379-6

Hinz, H., Prieto, V., Kaiser, M.J., 2009. Trawl disturbance on benthic communities: Chronic effects and experimental predictions. Ecol. Appl. 19, 761-773. https://doi.org/10.1890/08-0351.1

Hinz, H., Hiddink, J.G., Forde, J., Kaiser, M.J., 2008. Large-scale responses of nematode communities to chronic otter-trawl disturbance. Can. J. Fish. Aquat. Sci. 65, 723-32.

Howarth, L.M., Roberts, C.M., Thurstan, R.H., Stewart, B.D., 2014. The unintended consequences of simplifying the sea: Making the case for complexity. Fish Fish. 15, 690-711. https://doi.org/10.1111/faf.12041

ICES, 2018. ICES Advice on fishing opportunities, catch, and effort, Greater North Sea Ecoregion. Cod (Gadus morhua) in Subdivision 21 (Kattegat). Published 29 June 2018 
Jennings, S., Dinmore, T.A., Duplisea, D.E., Warr, K.J., Lancaster, J.E., 2001. Trawling disturbance can modify benthic production processes. J. Anim. Ecol. 70, 459-475. https://doi.org/10.1046/j.1365-2656.2001.00504.x Jennings, S., Nicholson, M.D., Dinmore, T.A., Lancaster, J.E., 2002. Effects of chronic trawling disturbance on the production of infaunal communities. Mar. Ecol. Prog. Ser. 243, 251-260. https://doi.org/10.3354/meps243251

Josefson, A.B., Jensen, J.N., 1992. Growth patterns of Amphiura filiformis support the hypothesis of organic enrichment in the Skagerrak-Kattegat area. Mar. Biol. 112, 615-624. https://doi.org/10.1007/BF00346179

Josefson, A.B., Loo, L.O., Blomqvist, M., Rolandsson, J., 2018. Substantial changes in the depth distributions of benthic invertebrates in the eastern Kattegat since the 1880s. Ecol. Evol. https://doi.org/10.1002/ece3.4395

Kaiser, M.J., Clarke, K.R., Hinz, H., Austen, M.C.V., Somerfield, P.J., Karakassis, I., 2006. Global analysis of response and recovery of benthic biota to fishing. Mar. Ecol. Prog. Ser. 311, 1-14. https://doi.org/10.3354/meps311001

Kaiser, M.J., Edwards, D.B., Armstrong, P.J., Radford, K., Lough, N.E.L., Flatt, R.P., Jones, H.D., 1998. Changes in megafaunal benthic communities in different habitats after trawling disturbance. ICES J. Mar. Sci. 55, 353361. https://doi.org/10.1006/jmsc.1997.0322

Kaiser, M.J., Ramsay, K., Richardson, C.A., Spence, F.E., Brand, A.R., 2000. Chronic fishing disturbance has changed shelf sea benthic community structure. J. Anim. Ecol. https://doi.org/10.1046/j.13652656.2000.00412.x

Laliberté, E., Legendre, P., \& Shipley, B. (2015). FD: measuring functional diversity from multiple traits, and other tools for functional ecology. R Package, Version 1.0-12

Laliberté, E., Legendre, P., 2010. A distance-based framework for measuring functional diversity from multiple traits. Ecology 91, 299-305. https://doi.org/10.1890/08-2244.1

Lambert, G.I., Jennings, S., Hiddink, J.G., Hintzen, N.T., Hinz, H., Kaiser, M.J., Murray, L.G., 2012. Implications of using alternative methods of vessel monitoring system (VMS) data analysis to describe fishing activities and impacts. ICES J. Mar. Sci. 69, 682-693. https://doi.org/10.1093/icesjms/fss018

Lehmann, A., Hinrichsen, H.H., Getzlaff, K., Myrberg, K., 2014. Quantifying the heterogeneity of hypoxic and anoxic areas in the Baltic Sea by a simplified coupled hydrodynamic-oxygen consumption model approach. J. Mar. Syst. https://doi.org/10.1016/j.jmarsys.2014.02.012

Lepš, J., De Bello, F., Lavorel, S., Berman, S., 2006. Quantifying and interpreting functional diversity of natural communities: practical considerations matter. Preslia 78, 481-501. https://doi.org/halsde-00293183

Lüdecke, D., 2016 sjPlot: Data Visualization for Statistics in Social Science. 2019; Available online: http: //cran.r-project.org/package=sjPlot 
Malhi, Y., Doughty, C.E., Galetti, M., Smith, F.A., Svenning, J.-C., Terborgh, J.W., 2016. Megafauna and ecosystem function from the Pleistocene to the Anthropocene. Proc. Natl. Acad. Sci. 113, 838-846. https://doi.org/10.1073/pnas.1502540113

Mangano, M.C., Kaiser, M.J., Porporato, E.M.D., Lambert, G.I., Rinelli, P., Spanò, N., 2014. Infaunal community responses to a gradient of trawling disturbance and a long-term Fishery Exclusion Zone in the Southern Tyrrhenian Sea. Cont. Shelf Res. 76, 25-35. https://doi.org/10.1016/j.csr.2013.12.014

McConnaughey, R. a, Syrjala, S.E., Dew, C.B., 2005. Effects of chronic bottom trawling on the size structure of soft-bottom benthic invertebrates. Benthic habitats Eff. fishing. Am. Fish. Soc. Symp. 41 425-437.

Ministry of Foreign Affairs of Denmark, 1933b. Anordning om frednings- og ordensbestemmelser af fiskeriet i det til kongerigerne Danmark og Sverige grænsende farvande. Royal Regulation, AND no. 230 of 29/06/1933, 2 pp. DOI: https://www.retsinformation.dk/Forms/R0710.aspx?id=79587

Ministry of Foreign Affairs of Denmark. 1933a. Bekendtgørelse om en under 31. December 1932 mellem Danmark og Sverige angaaende fiskeriforholdende i de til Danmark og Sverige grænsende farvande. BEK no. 228 of 21/06/1933, Ministry of Foreign Affairs of Denmark, J.nr. 63.D.31, pp 1-5. DOI: https://www.retsinformation.dk/pdfPrint.aspx?id=163290

Ministry of Foreign Affairs of Denmark. 2009. Bekendtgørelse om forbud mod visse former for fiskeri $\mathrm{i}$ nærmere afgrænsede områder i Kattegat og nordlige del af Øresund. BEK no. 182 of 13/03/2009, Ministry of Food, Agriculture and Fishery, Fisheries Agency, J.nr. 2009-01657, pp 1-8. DOI: https://www.retsinformation.dk/pdfPrint.aspx?id=123851

Norkko, A., Villnäs, A., Norkko, J., Valanko, S., Pilditch, C., 2013. Size matters: Implications of the loss of large individuals for ecosystem function. Sci. Rep. 3, 2646. https://doi.org/10.1038/srep02646

Pearson, T.H., Rosenberg, R., 1978. Macrobenthic succession in relation to organic enrichment and pollution of the marine environment. Oceanogr. Mar. Biol. Ann. Rev. 16, 229-311

Petersen CGJ (1918) The sea bottom and its production of fish food. A survey of the work done in connection with the valuation of the Danish waters from 1883-1917. Rep Danish Biol Station 25: 1-62

Pommer, C.D., Olesen, M., Jhansen, $\varnothing$.L.S., 2016. Impact and distribution of bottom trawl fishing on mudbottom communities in the Kattegat. Mar. Ecol. Prog. Ser. 548, 47-60. https://doi.org/10.3354/meps11649

Puig, P., Canals, M., Company, J.B., Martín, J., Amblas, D., Lastras, G., Palanques, A., Calafat, A.M., 2012. Ploughing the deep sea floor. Nature. https://doi.org/10.1038/nature11410

Queirós, A.M., Hiddink, J.G., Kaiser, M.J., Hinz, H., 2006. Effects of chronic bottom trawling disturbance on benthic biomass, production and size spectra in different habitats. J. Exp. Mar. Bio. Ecol. 335, 91-103. https://doi.org/10.1016/j.jembe.2006.03.001

R Core Team, 2018. R: A Language and Environment for Statistical Computing. R Foundation for Statistical Computing, Vienna, Austria URL. https://www.R-project. org/.

Reiss, H., Greenstreet, S.P.R., Sieben, K., Ehrich, S., Piet, G.J., Quirijns, F., Robinson, L., Wolff, W.J., Kröncke, I., 2009. Effects of fishing disturbance on benthic communities and secondary production within an intensively fished area. Mar. Ecol. Prog. Ser. 394, 201-213. https://doi.org/10.3354/meps08243 
Rice, J., Arvanitidis, C., Borja, A., Frid, C., Hiddink, J.G., Krause, J., Lorance, P., Ragnarsson, S.Á., Sköld, M., Trabucco, B., Enserink, L., Norkko, A., 2012. Indicators for sea-floor integrity under the european marine strategy framework directive. Ecol. Indic. 12, 174-184. https://doi.org/10.1016/j.ecolind.2011.03.021

Rijnsdorp, A.D., Bolam, S.G., Garcia, C., Hiddink, J.G., Hintzen, N.T., van Denderen, P.D., van Kooten, T., 2018. Estimating sensitivity of seabed habitats to disturbance by bottom trawling based on the longevity of benthic fauna. Ecol. Appl. 28, 1302-1312. https://doi.org/10.1002/eap.1731

Sciberras, M., Hiddink, J.G., Jennings, S., Szostek, C.L., Hughes, K.M., Kneafsey, B., Clarke, L.J., Ellis, N., Rijnsdorp, A.D., McConnaughey, R.A., Hilborn, R., Collie, J.S., Pitcher, C.R., Amoroso, R.O., Parma, A.M., Suuronen, P., Kaiser, M.J., 2018. Response of benthic fauna to experimental bottom fishing: A global metaanalysis. Fish Fish. 19, 698-715. https://doi.org/10.1111/faf.12283

Sciberras, M., Parker, R., Powell, C., Robertson, C., Kröger, S., Bolam, S., Geert Hiddink, J., 2016. Impacts of bottom fishing on the sediment infaunal community and biogeochemistry of cohesive and non-cohesive sediments. Limnol. Oceanogr. 61, 2076-2089. https://doi.org/10.1002/Ino.10354

Shannon, C.E., 1948. The mathematical theory of communication. Bell Syst. Tech. J. https://doi.org/10.2307/3611062

Shin, Y.J., Rochet, M.J., Jennings, S., Field, J.G., Gislason, H., 2005. Using size-based indicators to evaluate the ecosystem effects of fishing. ICES J. Mar. Sci. 62, 384-396. https://doi.org/10.1016/j.icesjms.2005.01.004

Sköld, M., Göransson, P., Jonsson, P., Bastardie, F., Blomqvist, M., Agrenius, S., Hiddink, J.G., Nilsson, H.C., Bartolino, V., 2018. Effects of chronic bottom trawling on soft-seafloor macrofauna in the Kattegat. Mar. Ecol. Prog. Ser. 586, 41-55. https://doi.org/10.3354/meps12434

Sköld, M., Josefson, A., Loo, L., 2001. Sigmoidal growth in the brittle star Amphiura filiformis (Echinodermata: Ophiuroidea). Mar. Biol. 139, 519-526. https://doi.org/10.1007/s002270100600

Solan, M., Cardinale, B.J., Downing, A.L., Engelhardt, K.A.M., Ruesink, J.L., Srivastava, D.S., 2004. Extinction and ecosystem function in the marine benthos. Science (80-. ). https://doi.org/10.1126/science.1103960

Svedäng, H., Bardon, G., 2003. Spatial and temporal aspects of the decline in cod (Gadus morhua L.) abundance in the Kattegat and eastern Skagerrak. ICES J. Mar. Sci. 60, 32-37. https://doi.org/10.1006/jmsc.2002.1330

Thrush, A.S.F., Hewitt, J.E., Cummings, V.J., Dayton, P.K., Cryer, M., Turner, S.J., Funnell, G.A., Budd, R.G., Milburn, C.J., Wilkinson, M.R., 2008. Disturbance of the Marine Benthic Habitat by Commercial Fishing: Impacts at the Scale of the Fishery Published by: Ecological Society of America Stable URL: http://www.jstor.org/stable/2641273 $\quad 8, \quad$ 866-879. $\quad$ https://doi.org/10.1890/10510761(1998)008[0866:DOTMBH]2.0.CO;2

Thrush, S.F., Hewitt, J.E., Gibbs, M., Lundquist, C., Norkko, A., 2006. Functional role of large organisms in intertidal communities: Community effects and ecosystem function. Ecosystems 9, 1029-1040. https://doi.org/10.1007/s10021-005-0068-8 
Tillin, H.M., Hiddink, J.G., Jennings, S., Kaiser, M.J., 2006. Chronic bottom trawling alters the functional composition of benthic invertebrate communities on a sea-basin scale. Mar. Ecol. Prog. Ser. 318, 31-45. https://doi.org/10.3354/meps318031

Van Denderen, P.D., Bolam, S.G., Hiddink, J.G., Jennings, S., Kenny, A., Rijnsdorp, A.D., Van Kooten, T., 2015. Similar effects of bottom trawling and natural disturbance on composition and function of benthic communities across habitats. Mar. Ecol. Prog. Ser. 541, 31-43. https://doi.org/10.3354/meps11550

Van Hoey, G., Borja, A., Birchenough, S., Buhl-Mortensen, L., Degraer, S., Fleischer, D., Kerckhof, F., Magni, P., Muxika, I., Reiss, H., Schröder, A., Zettler, M.L., 2010. The use of benthic indicators in Europe: From the water framework directive to the marine strategy framework directive. Mar. Pollut. Bull. 60, 2187-2196. https://doi.org/10.1016/j.marpolbul.2010.09.015

Villéger, S., Mason, N.W.H., Mouillot, D., 2008. New multidimensional functional diversity indices for a multifaceted framework in functional ecology. Ecology.

Wei T, Simko V (2016) Package 'corrplot'. R package version 0.77. https://cran.rproject.org/web/packages/corrplot/.

Woodward, G., Ebenman, B., Emmerson, M., Montoya, J.M., Olesen, J.M., Valido, A., Warren, P.H., 2005. Body size in ecological networks. Trends Ecol. Evol. https://doi.org/10.1016/j.tree.2005.04.005

WoRMS Editorial Board (2018). World Register of Marine Species. Available from http://www.marinespecies.org at VLIZ. Accessed 05/06/2018. doi:10.14284/170 